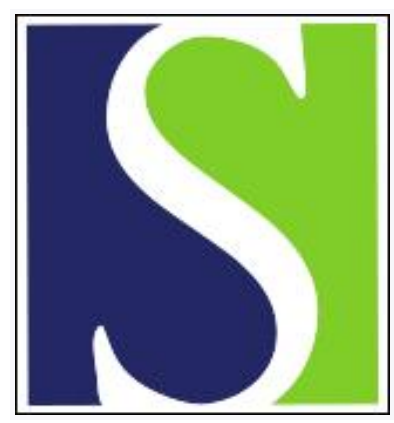

Scand J Work Environ Health 2011;37(6):473-480

https://doi.org/10.5271/sjweh.3181

Published online: 02 Jul 2011, Issue date: Nov 2011

Factors influencing the decision to extend working life or retire

by Nilsson K, Hydbom AR, Rylander L

Affiliation: Department of Work Science, Economic \& Environmental Psychology, Swedish University Agricultural Science, Box 88, 23053

Alnarp, Sweden. kerstin.nilsson@slu.se

Refers to the following texts of the Journal: 1997;23 suppl 1:3-6

1997;23 suppl 1:27-35

The following articles refer to this text: 2011;37(6):451-453;

2013;39(2):125-133; 2013;39(2):134-143; 2013;39(3):233-240; 2017;43(1):24-33

Key terms: employee; extending working life; motivation; older worker; organization; retirement; work ability; work environment; working life

This article in PubMed: www.ncbi.nlm.nih.gov/pubmed/21725583 


\title{
Factors influencing the decision to extend working life or retire
}

\author{
By Kerstin Nilsson MPH, ${ }^{1,2}$ Anna Rignell Hydbom PhD, ${ }^{1}$ Lars Rylander PhD ${ }^{1}$
}

\begin{abstract}
Nilsson K, Hydbom AR, Rylander L. Factors influencing the decision to extend working life or retire. Scand J Work Environ Health. 2011;37(6):473-480. doi:10.5271/sjweh.3181

Objective The aim of this study was to evaluate factors within nine identified areas that influence why some older workers want to (or believe they can) work until age 65 years or beyond, whereas others leave the workforce earlier.

Methods The questionnaire-based, cross-sectional study included 1792 respondents aged 55-64 years, employed in the healthcare sector in Sweden. Using logistic regression, we investigated the associations between statements within nine areas and two outcome measures: (i) whether the individual wanted to work until age 65 years or beyond and (ii) whether the individual believed they can work until age 65 years or beyond.
\end{abstract}

Results Of the 1792 respondents, 54\% stated that they "can" and 38\% that they "want to" work until age 65 years or beyond. Three areas were significantly associated with both these outcomes: worker health, economic incentives, and retirement decisions by life partners or close friends. Mental and physical working environment, work pace and skills/competence were associated with the "can" outcome, whereas work as an important part of life, working time, and management attitude to older workers were associated with the "want to" outcome.

Conclusion Although there were differences regarding the associations between six of the areas and the two outcomes (ie, "can" and "want to" go on working until age 65 years or beyond), three of the areas were important to both outcomes. Among those, it was interesting that life partner or close social environment gave higher odds ratios than for example health, physical work environment, or work satisfaction.

Key terms employee; motivation; older worker; organization; retirement; work ability; work environment.

In most of the industrial world, the fraction of older people is continuously increasing (1). A work session on demographic projections in Lisbon in 2010 stated that current demographic trends, characterized by low fertility and increasing longevity and leading to an ageing population, have economic and budgetary implications (2). A consequence analysis carried out by the Organization for Economic Cooperation and Development (OECD) compared the elderly boom to the social effect arising from natural disasters (3). In the OECD countries, it is estimated that $29 \%$ of men and $34 \%$ of women will be $\geq 60$ years in 2050 , compared with $15 \%$ of men and $20 \%$ of women in 2000 (4). In the EU25 (European Union of 25 members), more than 33\% of men and $38 \%$ of women are estimated to be $\geq 60$ years in 2050 , up from $18 \%$ of men and $24 \%$ of women in
2000 (4). The demographic situation is similar in most of the Western world and in the Nordic countries, as illustrated by the following predicted figures for men and women, respectively, in 2050: USA 24\% and 28\%; Sweden $28 \%$ and $30 \%$; Finland $31 \%$ and $35 \%$; Germany $34 \%$ and $39 \%$ (4).

The demographic change will result in an increased old age dependency ratio when fewer in the workforce have to provide for more elderly people. For the EU27, the old age dependency ratio is expected to rise from $25 \%$ in 2008 to $38 \%$ in 2030 . In other words, 100 people in the working population supported 25 people aged $\geq 65$ years in 2008, but they are estimated to support 38 people by 2030 (5). In addition, the policies in 21 countries regarding the social protection system, including old age and disability pension, a negative attitude to older

\footnotetext{
1 Division of Occupational and Environmental Medicine, Lund University, Sweden.

2 Department of Work Science, Economic \& Environmental Psychology, Swedish University Agricultural Science, Sweden.
}

Correspondence to: Kerstin Nilsson, Department of Work Science, Economic \& Environmental Psychology, Swedish University Agricultural Science, Box 88, 23053 Alnarp, Sweden. [E-mail: kerstin.nilsson@slu.se] 
workers, and ill-suited working conditions force older workers into early retirement (6). As a consequence of the ageing population, society has to increase the number of working hours in the economy, which stresses the importance of motivating the population to work to an older age in order to maintain the welfare state. Several European countries have already decided to take this step (7-9).

Most of the theoretical models that are used in retirement studies are not developed specifically to consider old age retirement but rather economics, organizational and social needs, personal development, wellbeing, and health (10). Good physique, mental health, and work ability are often reported to be very important factors for whether people are able to continue their working life or take sick leave or some form of retirement (10, 11, 15-29). Health has been called a key determinant of early retirement (30).

Another factor often described in earlier retirement studies is economic: personal finances and retirement incentives (eg, incentives that keep employees in the workforce through poverty or pull them into retirement and make it possible to stop working through economic well-being) (10, 13, 14, 22, 26, 30-33).

Poor physical work environment and arduous work conditions leave people worn out and push them to leave working life early $(15,21,34-39)$. Some studies have shown that older workers seem to need more time to rest, and highlight moderate working pace and working time as being very important for the older workforce (1, $10,11,23,26,38)$.

Mental work conditions, stress and job control have also been mentioned as important predictors for people's retirement planning, and retirement seems to be a possible socially acceptable way to withdraw from a demanding work situation $(10,11,15,21,25-28,34-39)$.

Feeling satisfied with the daily work and receiving attention in the work situation have been cited as important factors in the intention to extend working life $(15,22,23,28,40,41)$. This is particularly the case if the attitude is positive, and older workers are treated as wise and experienced, or negative (ie, there is a stereotypical picture of older workers as stagnant and an encumbrance) $(23,26,42,43)$.

Another factor that affects the decision to extend working life according to previous research is the level of education, competence, and possibility for skills development of older workers, but also whether they are able to use their skills in their work $(17,19,26,31,40$, $44,45)$. But it is not only working life that matters. The prevailing attitude of society, marital status, whether the life partner is working, or if the older worker wants to spend more time with relatives and leisure pursuits may influence individuals to withdraw from working life (12, $15,19,22,26,29,46-48)$.
The decision to retire is complex, multidisciplinary and involves a lot of different research areas. However, earlier studies have shown that personal factors (such as health and economic well-being) and environmental factors (such as work characteristics and leisure interest) both influence the planning of and decisions about retirement $(1,10,11)$. Some factors seem to influence workers to stay in the workforce, whereas others seem to pull or push workers to leave the workforce $(10,12-14)$. A review of old age policies in 21 countries concluded that the current social protection system, including old age and disability pension, pulls older workers into early retirement (6). At the same time, a negative attitude to older workers together with ill-suited working conditions for their needs and capacity push older workers out of work (6).

The aim of this cross-sectional study, among healthcare personnel ranging in age from 55-64 years and working in southern Sweden, was to evaluate the main factors associated with why people want to, or believe they can, work until age 65 years or beyond. The reason for this is that even though an individual is pulled or pushed and able to do something does not mean that they want to do it, and vice versa. To better understand the retirement planning process, it is therefore of particular interest to examine the "can" and "want to" perspectives and investigate how different factors are associated with perspectives from earlier studies and retirement theories.

\section{Methods}

The dataset used in this study originated from a Swedish National Institute of Working Life study in 2004, which examined factors of interest for retirement.

\section{Study population}

The initial study population identified consisted of 2822 individuals born between 1940-1949. Subjects were identified by the personnel register as being employed in the health and medical care service in Scania, the most southern county in Sweden. The study population had the same employer, which minimized the risk of different employment conditions, rehabilitation policies, and retirement policies (49). Working in the public sector has been associated with early withdrawal from the working life in a previous study (26).

The individuals in this study were sent a questionnaire by post. After two reminders, 1815 individuals answered the questionnaire. However, 23 individuals did not state whether they think they can and want to work $\geq 65$ years. Those individuals were excluded from the study, resulting in a total of 1792 individuals in the final 
study population. This corresponded to a response rate of $63.5 \%$. The majority of the participants were women $(84 \%)$. In addition, women had a higher response rate (68\%) compared with men $(59 \%)$. The median age among the participants was 59 years, which was very similar to that of the non-respondents ( 58 years).

The distribution of occupations among the participants was: $21 \%$ nurses, $20 \%$ medical secretaries, $17 \%$ doctors, $15 \%$ nursing assistants, $7 \%$ physiotherapists, $7 \%$ welfare officers, $5 \%$ psychologists, $5 \%$ psychiatric nursing assistants, and 3\% occupational therapists. The proportion of non-participants was highest among doctors $(25 \%)$ and lowest among physiotherapists, occupational therapists, psychologists, and welfare officers $(14 \%)$. In all, $13 \%$ of the respondents were on part- or full-time sick leave and $16 \%$ had a part- or full-time disability pension. Of the participants, $91 \%$ were born in Sweden, 4\% in another Nordic country, 4\% in nonNordic European country and 1\% outside Europe. As regards civil status, $75 \%$ of the participants were married/co-habiting, $4 \%$ were partly co-habiting, and $21 \%$ were single. Among the participants with a partner, $61 \%$ had a partner who worked full-time, $13 \%$ had a partner who worked part-time, and $26 \%$ had a partner who did not work at all.

\section{Questionnaire}

Two questions formed the basis for the outcomes in this study. The first question was whether the respondent wants to work until 55-59, 60-64, 65, or $\geq 66$ years of age and the second question was whether the participant believes they can work until $55-59,60-64,65$, or $\geq 66$ years of age. The answering options were dichotomized at 65 years of age (ie, working until $<65$ versus $\geq 65$ years of age).

Originally the participants filled in a questionnaire that included 158 statements. For each statement, the participants had five answering options ranging from fully agree to fully disagree. The answers to each statement were then sorted into three categories; fully agree, neither fully agree nor fully disagree, and fully disagree. Based on previous knowledge within this research field, the statements were sorted into nine areas. The selection of the statements was based on previous studies performed by our research group $(15,40)$, a literature review (50), and other surveys (51-54). The questionnaire was tested in a group of 15 individuals employed within the healthcare sector. Evaluation of this pilot process resulted in reformulation of a few statements.

In our study, we used 65 of the 158 original statements. They were sorted into nine areas: (i) physical and mental health (9 statements), (ii) personal economic incentives (8 statements), (iii) physical work environment (3 statements), (iv) mental work environment (9 statements), (v) work pace and working time (8 statements), (vi) managerial and organizational attitude to older workers (6 statements), (vii) competence and possibility for skills development (10 statements), (viii) motivation and work satisfaction (7 statements), and (ix) family/leisure pursuits and attitude to pension in society (5 statements).

\section{Statistical analysis}

Logistic regression models generating odds ratios (OR), 95\% confidence intervals $(95 \% \mathrm{CI})$, and P-values were used to investigate the statements associated with the outcomes "want to work until age 65 years or beyond" and "can work until age 65 years or beyond". For each of the two outcomes, we used the following analytical strategy.

Analyses within each of the nine areas. We started with univariate analyses (ie, we evaluated the associations for one statement at a time). In a second step, we kept the statement with the lowest $\mathrm{P}$-value (if $\mathrm{P}<0.05$ ) and tentatively included all other statements, one at a time. In a third step, we kept the two statements with the lowest $\mathrm{P}$-values (if both $\mathrm{P}<0.05$ ) and tentatively included the remaining statements one at a time. This procedure continued for as long as the P-values for all included statements were $<0.05$.

Analyses including all nine areas. We started by including the selected statements from areas (i) and (ii) in a multivariate model (ie, the areas "physical and mental health" and "personal economic incentives"). The statements with P-values $<0.05$ were kept in the model to the next step, in which we also included the selected statements from area (iii). This procedure continued until all nine areas were included in a final model. After that, the out-sorted statements from the nine areas were tested, one at a time, in the final model, to check once more if the model was robust.

Background variables. In the final multivariate model, we also evaluated the importance of background variables (age, gender, and marital status) by including them in the model.

\section{Results}

\section{Outcomes}

The proportion of individuals who stated that they can work until age 65 years or beyond was 54\% (table 1). A higher proportion was observed among the older participants (62\%), ie, those in the age range 60-64 years, 
compared with the younger participants $(48 \%)$. The proportion of individuals who stated that they want to work until age 65 years or beyond was $38 \%$ (table 2). Again, the proportion was higher among the older (47\%) than younger participants (33\%).

Out of the 1792 respondents, $36 \%$ stated that they can and want to work until age 65 years or beyond, $44 \%$ stated that they can and want to work until 55-64 years of age, $17 \%$ stated that can work until age 65 years or beyond but they only want to work until 55-64 years of age, and 3\% stated that they can work until 55-64 years of age but they want to work until age 65 years or beyond.

\section{Statements associated with "can" work}

In the final multivariate model, 11 statements were statistically significantly associated with "can work until age 65 years or beyond" (table 3 ). The statements were from seven of the nine areas. Three statements were from the area "personal economic incentives" and two from the area "physical and mental health". Those areas that were not represented in the final model were "motivation and work satisfaction" and "managerial and organizational attitude to older workers".

The strongest observed association, defined as the highest OR, was for the statement "I hope for an offer from my employer to stop working before age 65 ". Comparing the individuals who disagreed with this statement with those who agreed with it gave an OR of $4.3(95 \% \mathrm{CI}$ 3.2-5.9). The second strongest association was observed within the area "mental work environment". Comparing the individuals who disagreed with the statement "my work is too mentally demanding for working until age

Table 1. Proportion of respondents in the age classes $55-59$ and 60-64 years who believed they "can" work to 55-59, 60-64, 65 and $>66$ years.

\begin{tabular}{|c|c|c|c|c|c|c|c|c|}
\hline \multirow{3}{*}{$\begin{array}{l}\text { Age of } \\
\text { respondent }\end{array}$} & \multicolumn{8}{|c|}{ Age (years) to which respondents believed they can work } \\
\hline & \multicolumn{2}{|c|}{$55-59$} & \multicolumn{2}{|c|}{$60-64$} & \multicolumn{2}{|c|}{65} & \multicolumn{2}{|c|}{$\geq 66$} \\
\hline & $\mathrm{N}$ & $\%$ & $\mathrm{~N}$ & $\%$ & $\mathrm{~N}$ & $\%$ & $\mathrm{~N}$ & $\%$ \\
\hline $\begin{array}{l}55-59 \\
60-64 \\
\text { All }\end{array}$ & $\begin{array}{l}86 \\
10 \\
96\end{array}$ & $\begin{array}{l}7.9 \\
1.4 \\
5.3\end{array}$ & $\begin{array}{l}485 \\
261 \\
746\end{array}$ & $\begin{array}{l}45 \\
37 \\
42\end{array}$ & $\begin{array}{l}367 \\
309 \\
676\end{array}$ & $\begin{array}{l}34 \\
44 \\
38\end{array}$ & $\begin{array}{l}149 \\
131 \\
280\end{array}$ & $\begin{array}{l}14 \\
18 \\
16\end{array}$ \\
\hline
\end{tabular}

Table 2. Proportion (\%) of respondents in the age classes 55-59 and 60-64 years who "want to" work to 55-59, 60-64, 65 and $>66$ years.

\begin{tabular}{|c|c|c|c|c|c|c|c|c|}
\hline \multirow{3}{*}{$\begin{array}{l}\text { Age of } \\
\text { respondent }\end{array}$} & \multicolumn{8}{|c|}{ Age (years) to which respondents want to work } \\
\hline & \multicolumn{2}{|c|}{$55-59$} & \multicolumn{2}{|c|}{$60-64$} & \multicolumn{2}{|c|}{65} & \multicolumn{2}{|c|}{$\geq 66$} \\
\hline & $\mathrm{N}$ & $\%$ & $\mathrm{~N}$ & $\%$ & $\mathrm{~N}$ & $\%$ & $\mathrm{~N}$ & $\%$ \\
\hline $\begin{array}{l}55-59 \\
60-64 \\
\text { All }\end{array}$ & $\begin{array}{r}154 \\
30 \\
184\end{array}$ & $\begin{array}{r}14 \\
4.2 \\
10\end{array}$ & $\begin{array}{l}574 \\
351 \\
925\end{array}$ & $\begin{array}{l}53 \\
49 \\
51\end{array}$ & $\begin{array}{l}271 \\
233 \\
504\end{array}$ & $\begin{array}{l}25 \\
33 \\
28\end{array}$ & $\begin{array}{r}89 \\
99 \\
188\end{array}$ & $\begin{array}{r}8.2 \\
14 \\
10\end{array}$ \\
\hline
\end{tabular}

Table 3. Distributions regarding "can" outcome for statements included in final multivariate model. Increased odds ratio (OR) indicate individuals believed they have increased possibility to work age $\geq 65$ years. [ $95 \% \mathrm{Cl}=95 \%$ confidence interval; Ref=reference.]

\begin{tabular}{|c|c|c|}
\hline \multirow[t]{2}{*}{$\begin{array}{l}\text { Agree or disagree with } \\
\text { the statement in each area }\end{array}$} & $\begin{array}{l}\text { Univariate } \\
\text { estimates }\end{array}$ & $\begin{array}{l}\text { Multivariate } \\
\text { model }\end{array}$ \\
\hline & OR $\quad 95 \% \mathrm{Cl}$ & OR $\quad 95 \% \mathrm{Cl}$ \\
\hline
\end{tabular}

Physical and mental health

I feel mentally worn out

Agree

Partly agree

Ref Ref

Disagree

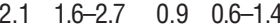

I have bad health and have/am probably

going to get disability pension before age 65

\begin{tabular}{lllll} 
Agree & Ref & \multicolumn{3}{c}{ Ref } \\
Partly agree & 5.0 & $3.5-7.2$ & 1.6 & $1.7-4.3$ \\
Disagree & 3.3 & $3.3-6.2$ & 2.6 & $1.4-3.4$
\end{tabular}

Personal economic incentives

I am saving in different ways to make it possible to stop working before age 65 .

Agree

Partly agree

Ref Ref

$\begin{array}{llll}2.9 & 2.2-3.8 & 1.6 & 1.1-2.3\end{array}$

Disagree

$\begin{array}{llll}6.9 & 5.5-8.8 & 2.6 & 1.9-3.6\end{array}$

My intention is to work beyond age 65 to

get a better pension

Disagree

Partly agree

Agree

I hope for an offer from my employer to

stop working before age 65

Agree

Partly agree

Disagree

Ref Ref

$\begin{array}{llll}3.0 & 2.1-4.1 & 1.8 & 1.1-2.8\end{array}$

$\begin{array}{llll}5.4 & 3.9-7.6 & 1.9 & 1.2-3.0\end{array}$

\begin{tabular}{rrrr} 
Ref & \multicolumn{3}{c}{ Ref } \\
3.7 & $2.7-5.0$ & 2.1 & $1.4-3.1$ \\
13 & $10-17$ & 4.3 & $3.2-5.9$
\end{tabular}

Physical work environment

My work is too physically demanding for working age $\geq 65$ years

Agree

Partly agree

Disagree

Mental work environment

My work is too mentally demanding for

working age $\geq 65$ years

Agree

Partly agree

Disagree

Ref

$\begin{array}{llll}3.5 & 2.7-4.6 & 2.1 & 1.4-3.0\end{array}$

$\begin{array}{llll}12 & 9.2-15 & 4.0 & 2.8-5.7\end{array}$

Working pace and working time

The working pace in my daily work is rapid Agree

Partly agree

Disagree

Ref Ref

$\begin{array}{llll}1.4 & 1.1-1.8 & 1.0 & 0.7-1.5\end{array}$

$2.5 \quad 1.9-3.1 \quad 1.5 \quad 1.0-2.1$

Competence and possibility for skills development

I feel that my competence is used in a satisfactory way within the organisation

Disagree

Partly agree

Agree

Due to my age I get fewer possibilities to

be supervised

Agree

Partly agree

Disagree

Family/leisure pursuits and attitude to pension in society

I will stop working before age 65 when my life partner/close friend stops working Agree

Partly agree

Ref Ref

Disagree 
65 years or beyond" with those who agreed with it gave an OR of 4.0 (95\% CI 2.8-5.7). When the background variables age, gender and marital status were included in the final model, the OR changed only marginally (data not shown).

\section{Statements associated with "want to" work}

In the final multivariate model, 12 statements from five of the nine areas were associated with "I want to work until 65 years of age or beyond" (table 4). None of the statements from the areas "physical work environment", "mental work environment", "working pace and working time" and "competence and possibility for skills development" qualified for the final model. However, five statements from the area "personal economic incentives", three from the area "family/leisure pursuits and attitude to pension in society", and two from the area "managerial and organizational attitude to older workers" qualified for the final model.

The strongest association was observed for the statement "I will probably stop working before age 65 through an early age pension", included in the area "personal economic incentives". When comparing individuals who disagreed with this statement against those who agreed with it, an OR of 8.6 (95\% CI 4.8-15) was observed. A strong association was also observed for another statement within the same area; when comparing individuals who disagreed with the statement "I hope for an offer from my employer to stop working before age 65 " with those who agreed with it, an OR of 7.9 (95\% CI 5.4-11) was observed. When we included the background variables age, gender, and marital status in the final model, the OR changed only marginally (data not shown).

\section{Discussion}

This study indicated that there is a difference between "can" and "want to" work in an extended working life. There were more individuals who believed they can work than those who stated that they want to work until age 65 or beyond. Employees aged 60-64 years more often reported that they can and want to work until age 65 or beyond than those aged 55-59 years. The nine areas chosen to cover the field were based on earlier studies (10-51). Three of these areas were significantly associated with why people want to work, and why they think they can work, until 65 years or beyond. The results showed that the other six areas also influenced whether older workers believed they can as opposed to want to work until 65 years or beyond.

The study design was cross-sectional, which means that the results should be interpreted as the workers'
Table 4. Distributions regarding "want to" outcome for statements included in final multivariate model. Increased odds ratio (OR) indicate individuals believed they have increased possibility to work age $\geq 65$ years. [ $95 \% \mathrm{Cl}=95 \%$ confidence interval; Ref=reference.]

\begin{tabular}{|c|c|c|c|c|}
\hline \multirow[t]{2}{*}{$\begin{array}{l}\text { Agree or disagree with } \\
\text { the statement in each area }\end{array}$} & \multicolumn{2}{|c|}{$\begin{array}{l}\text { Univariate } \\
\text { estimates }\end{array}$} & \multicolumn{2}{|c|}{$\begin{array}{l}\text { Multivariate } \\
\text { model }\end{array}$} \\
\hline & $\mathrm{OR}$ & $95 \% \mathrm{Cl}$ & $\mathrm{OR}$ & $95 \% \mathrm{Cl}$ \\
\hline \multicolumn{5}{|l|}{ Physical and mental health } \\
\hline Agree & Ref & & Ref & \\
\hline Partly agree & 1.3 & $1.0-1.7$ & 1.2 & $0.8-1.9$ \\
\hline Disagree & 2.3 & $1.8-2.8$ & 2.0 & $1.4-2$ \\
\hline
\end{tabular}

Personal economic incentives

I will probably stop working before age 65 through early age pension a

$\begin{array}{lrrrr}\text { Agree } & \text { Ref } & & \text { Ref } \\ \text { Partly agree } & 6.1 & 4.3-8.6 & 1.8 & 1.2-2.9 \\ \text { Disagree } & 33 & 21-51 & 8.6 & 4.8-15\end{array}$

I am saving in different ways to make it

possible to stop working before age 65

Agree

Ref Ref

Partly agree

Disagree

$\begin{array}{llll}3.0 & 2.3-4.0 & 1.6 & 1.1-2.4\end{array}$

My intention is to work beyond age 65 to

get a better pension

Disagree

Partly agree

Agree

$\begin{array}{llll}9.6 & 7.3-13 & 2.2 & 1.5-3.3\end{array}$

I hope for an offer from my employer to stop working before age 65

Agree
Partly agree
Disagree

Ref Ref

$\begin{array}{llll}3.4 & 2.5-4.6 & 1.9 & 1.2-3.0\end{array}$

$\begin{array}{llll}7.1 & 5.3-9.8 & 2.2 & 1.4-3.5\end{array}$

Disagree

Ref Ref

$\begin{array}{llll}5.2 & 3.8-7.1 & 3.6 & 2.4-5.4\end{array}$

$\begin{array}{llll}27 & 20-36 & 7.9 & 5.4-11\end{array}$

do not want to decrease my number of working

hours even if my economic situation allows that

Disagree Ref

$\begin{array}{lllll}\text { Partly agree } \quad 2.6 & 2.0-3.4 & 2.4 & 1.6-3.6\end{array}$

Agree

$\begin{array}{llll}4.3 & 3.4-5.4 & 3.5 & 2.4-5.1\end{array}$

Attitude to older workers in the organization

There are special arrangements to adapt the work

situation to senior employees at my workplace

Disagree Ref

$\begin{array}{lllll}\text { Partly agree } & 1.8 & 1.4-2.2 & 1.9 & 1.4-2.7\end{array}$

Agree

The managers' attitude towards senior

employees is positive at my workplace

Disagree

Partly agree

Agree

$2.0 \quad 1.4-2.7 \quad 1.7 \quad 1.0-3.0$

Motivation and work satisfaction

My work is a very important part of my life

Disagree

Partly agree

Agree

Family/leisure pursuits and attitude to

pension in society

I will stop working before age 65 when

my life partner/close friend stops working

Agree

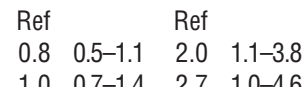

$\begin{array}{llll}0.8 & 0.5-1.1 & 2.0 & 1.1-3.8 \\ 1.0 & 0.7-1.4 & 2.7 & 1.0-4.6\end{array}$

Partly agree

Disagree

In my circle of acquaintances, it is common

to work beyond age 65

Disagree

Partly agree

Agree

Ref Ref

$\begin{array}{llll}4.9 & 1.9-12 & 2.2 & 0.8-6.3\end{array}$

$\begin{array}{llll}14 & 5.8-36 & 3.2 & 1.1-8.8\end{array}$

The common attitude in society is stop working before age 65

Agree

Partly agree

Ref Ref

$\begin{array}{llll}4.3 & 3.0-6.0 & 2.3 & 1.4-3.8\end{array}$

$\begin{array}{llll}23 & 14-37 & 4.8 & 2.6-8.8\end{array}$

Disagree

\begin{tabular}{llll} 
Ref & \multicolumn{3}{c}{ Ref } \\
2.3 & $1.8-3.0$ & 1.5 & $1.0-2.2$ \\
3.5 & $2.5-4.8$ & 1.9 & $1.1-3.3$
\end{tabular}

Ref Ref

$\begin{array}{llll}1.1 & 0.8-1.5 & 1.1 & 0.7-1.8\end{array}$

${ }^{a}$ Today possible from age 61 in Sweden. 
own attitudes and predictions about extended working life/retirement planning. The questionnaire was sent out after a review of the theoretical basis in the area and the majority of the statements in the questionnaire have previously been validated. In addition, a pilot study was performed to ensure that the statements included fulfilled the objectives. Although we had a relatively large number of participants in the study, a potential weakness was that $36.5 \%$ of the individuals in the original study population did not participate. Unfortunately, we have almost no information about the non-respondents and accordingly, it is not possible for us to estimate their importance. However, according to information from the diary used when people called to state that they did not want to participate, health and conflicts with managers seemed to be the most common reasons for non-participation.

It is also critical to consider that everyone included in the study population was employed. There could therefore have been a healthy worker effect and selection bias if those with poor health had already left the workforce. On the other hand, we used individuals working in the same workforce, and internal comparisons are reported to be one of the most effective ways of reducing the healthy worker effect (52).

The respondents were mostly women occupied in professions in the health and medical care sector, although there were less women among the doctors responding. Thus the study population consisted mostly of women, but that reflects the reality in the healthcare sector and the models were robust even after adjusting for gender. The models were also robust after adjusting for age and marital status.

Economic incentives and economic policy are previously well-known factors to pull or push older workers to retire or extend working life $(10,13,14,22,26$, $30-33)$. Compared with the other areas examined in this study, this seemed to be the most important factor for older workers when planning retirement and whether they believe they can and want to work until 65 years or beyond. Health was a slightly less important factor influencing whether older workers believe they can and want to extend their working life. Health is reported to improve after retirement among those in poor work situations (30), although being "pushed" into retirement can also result in increased mental health problems (11). Although individuals need good health to be able to work and have a good work capacity $(1,10,11,15-29)$, economics seemed to be of more importance than health status among the respondents in our study.

The reason why employees aged 60-64 years in this study more often reported that they can and want to work until 65 years could be that people often feel younger than their chronological age and seem to postpone the final decision to retire when they realize that retirement also involves the loss of the social ingredient and work status (15).

A surprise in this study was that life partners and close friends play such an important role regarding whether older workers believe they can, and want to, go on working past 65 years. This was more highly associated with extending the working life than, for example, health, physical work environment, or work satisfaction. Some previous studies have indicated the importance of marital status among women and change in marital status among men $(10,22,26,29)$. In this study, marital status was not significant in the model, but we included a direct statement in the questionnaire on whether the respondent was planning to retire at the same time as his/her life partner or close friends. The attitude in the surrounding environment is important in promoting healthy choices $(47,54)$, and the present study also indicated that the attitude in the close social environment is important for retirement planning. The attitude of society to retirement planning and time of retirement seems therefore to be an important factor to consider for a country intending to postpone people's retirement age.

One strength of this study was the possibility to determine differences between whether older workers believed they can and whether they want to extend their working life. All nine areas in the analysis had been identified in earlier studies as very important to retirement and retirement planning (10-48), but not all had been included in the same study. Furthermore, to the best of our knowledge earlier studies had made no distinction between whether older workers believed they "can" and/ or "want to" have an extended working life.

Mental and physical work environment, work pace, and skill and competence were particularly important factors in whether older workers believed they can work until 65 years of age or beyond. The mental work environment was also one of the most important factors in this respect. In addition, work as an important part of life and the attitude of managers and the organization toward older workers were important factors in the decision to extend working life. This "can" and "want to" perspective will hopefully make a contribution to understanding the retirement planning process. It does not contribute information on the factors that pull or push people out of working life, but rather examines the factors that make these older workers believe they "can" and/or "want to" work until 65 years of age or beyond. This knowledge can hopefully be important in intervention planning.

Due to the demographic change in society affecting human resources planning and the working life in the future (1-11), it is essential to continue studies within this research area. In such future research, it is important to test whether the models developed in this study continue to be robust when used for other sectors. 


\section{References}

1. Ilmarinen J. Toward a longer working life: Aging and quality of working life in the European Union. Helsinki: Finnish Institute of Occupational Health; 2006.

2. Eurostat, European Commission. Work session on demographic projections. Luxembourg: Publications Office of the European Union; 2010. Available from: http://epp.eurostat.ec.europa. eu/cache/ITY_OFFPUB/KS-RA-10-009/EN/KS-RA-10009-EN.PDF [cited 24 February 2011].

3. OECD. Emerging Risk in the 21st Century. An Agenda for Action. France: OECD Publication Service; 2003.

4. OECD. Population pyramids in 2000 and 2050. OECD Statistics Portal: Demography and Population; 2007. Available from: http://www.oecd.org/dataoecd/52/31/38123085.xls [cited 28 February 2011].

5. Giannakouris K. Regional population projections EUROPOP2008: Most EU regions face older population profile in 2030. Eurostat: Population and social conditions Statistics in focus; 2010. Available from: http://epp.eurostat. ec.europa.eu/cache/ITY_OFFPUB/KS-SF-10-001/EN/KSSF-10-001-EN.PDF [cited 3 March 2011].

6. OECD. Live longer, Work Longer. Paris. OECD; 2006.

7. Government Offices of Sweden. Inkluderande arbetsliv. [Inclusive working life.] Stockholm: SOU 2009:93. (In Swedish, summary in English.)

8. Swedish Ministry of Finance. Långtidsutredningen 2008. [The long-time survey 2008 of the Swedish Economy.] Stockholm: SOU 2008:105. (In Swedish.)

9. Labour Market Commission. Velfærd kræver arbejde. [Welfare request work.] Copenhagen: Labour Market Commission: 2009. (In Danish.)

10. Beehr TA. The process of retirement: a review and recommendations for future investigation. Personnel Psychology. 1986;39:31-55. doi:10.1111/j.1744-6570.1986. tb00573.x.

11. Taylor MA, Shore L. Predictors of Planned Retirement Age: An Application of Beehr's Model. Psychology and Aging. 1995;10:76-83. doi:10.1037/0882-7974.10.1.76.

12. Höög J. Arbetstillfredsställelse och frånvaro. [Work satisfaction and absence.] Umeå: Department of Sociology, Umeå University; 1985. (In Swedish.)

13. Stattin M. Yrke, yrkesförändring och utslagning från arbetsmarknaden. [Occupation, change of occupation and marginalization in labour market.] Umeå: Department of Sociology, Umeå University; 1998. (In Swedish.)

14. Höög J, Stattin M. Förtidspensioneringens utveckling och bakgrund. [The disability pensions development and background.] In: Marklund S, editor. Rehabilitering i ett samhällsperspektiv. [The societies perspective of rehabilitation.] Lund: Studentlitteratur; 1995. (In Swedish.)

15. Bengtsson E, Nilsson K. Äldre medarbetare. [Older worker.] Malmö: Swedish National Institute of Working life; 2004. (In Swedish.)
16. WHO. Active Ageing A Policy Framework. Spain: World Health Organization; 2002.

17. Kilbom Å, Torgén M. Fysisk förmåga och hälsa bland äldre i yrkeslivet. [Physical capacity and health among older people in working life.] In: Aronsson G, Kilbom Å, editors. Arbete efter 45. [Work after 45.] Stockholm: Swedish National Institute of Working life; 1996. (In Swedish.)

18. Hallsten L. Arbete och psykologiska åldersförändringar. [Work and mental age changes.] In: Aronsson G, Kilbom $\AA$, editors. Arbete efter 45. [Work after 45.] Stockholm: Swedish National Institute of Working life; 1996. (In Swedish.)

19. Nylén L, Torgén M. Under vilka förhållanden vill äldre personer yrkesarbeta? [In which conditions want older people to work?] Stockholm: Swedish National Institute of Working life. Work life report; 2002:2. (In Swedish.)

20. Ilmarinen J. Promotion of Work Ability during Aging. In: Kumashiro M, editors. Aging and Work. London: Taylor \& Francis; 2003.

21. Seitsamo J, Klockars M. Aging and changes in health. Scand J Work Environ Health. 1997;23:suppl 1:27-35.

22. Cobb-Clark DA, Stillman S. The Retirement Expectations of Middle-aged Australians. The Economic Record. 2009;85,269:146-163. doi:10.1111/j.1475-4932.2009.00543.x.

23. Saurama L. Experience of early exit. A comparative study of the reasons for and consequences of early retirement in Finland and Denmark in 1999-2000. Helsinki: Finnish Centre for Pension, Studies; 2004.

24. Anderson KH, Burkhauser RV, Quinn JF. Do retirement dreams come true? The effect of unanticipated events on retirement plans. Ind Lab Rel Rev. 1986;39:518-526. doi: $10.2307 / 2523244$.

25. von Bondsdorff ME. Intentions of Early Retirement and Continuing to Work Among Middle-aged and Older Emplyees. University of Jyväkyläl: Jyväskylä Studies in Business and Economics; 2009.

26. Forma P, Tuominen E, Väänänen-Tomppo I. Who wants to continue at work? Finnish pension reform and the future plans of older workers. Eur J Soc Sec. 2005;7:227-250.

27. Park J. Health factors and early retirement among older workers. Statistics Canada. 2010;75-001:5-13.

28. Siegrist J, Wahrendorf M, von dem Knesebeck O, Jürges H, Bösch-Supan A. Quality of work, well-being and intended early retirement of older employees - baseline results from the SHARE. Study. Eur J Pub Health. 2007;17:1,62-68. doi:10.1093/eurpub/ck1084.

29. Disney R, Tanner S. What can we learn from Retirement Expectations Data? University of Nottingham: The Institute of Fiscal Studies. Working Paper Series No. W99/17; 1999.

30. Roberts J, Rice N, Jones AM. Early Retirement Among Men in Britain and Germany: How Important is Health? The Geveva Papers. 2010;35:644-667. doi:10.1057/gpp.2010.24.

31. Soidre T. Vill vi jobba till 65 - eller kanske längre? [Do we want to work until 65 - or maybe longer?] Karlstad University: Arbetsmarknad \& Arbetsliv. 2005;11:2. (In Swedish.)

32. Coppola M, Benita Wilke C. How sensitive are subjective 
retirement expectations to increases in the statutory retirement age? The German case. Mannheim: Mannheim Research Institute for the Economics of Ageing, 207;2010.

33. Bösch-Supan A. Incentives effects of social security on labor force participation: Evidence in Germany and across Europe. J Pub Econ. 2000;78:25-49. doi:10.1016/S00472727(99)00110-3.

34. Munnell AH, Triest RH, Jivan N. How do pensions affect Expected and Actual Retirement Ages, CRR WP 2004-27. Boston: Center for Retirement research at Boston College; 2004.

35. Warr P. Age and Employment. In: Triandis HC, et al, editors. Handbook of Industrial and Organizational Psykology. vol 4. California: Consulting Psychologists Press Inc; 1994.

36. Pohjonen T. Perceived work ability of home care workers in relation to individual and work-related factors in different age groups. Occup Med. 2001;51:3:209-217. doi:10.1093/ occmed/51.3.209.

37. Volkoff S. The Statistical Study of the Links Between Age, Work and Health. In: Marquié JC, Cau-Bareille DP, Volkoff S, editors. Working with Age. London: Taylor \& Francis; 1998.

38. Hallsten L, Solem PE. Ålder och arbetsprestation. [Age and work ability.] In: Aronsson G, Kilbom A, editors. Arbete efter 45. [Work after 45.] Stockholm: Swedish National Institute of Working life; 1996. (In Swedish.)

39. Ilmarinen J, Louhevaara V. Finn Age - Respect for the aging: Action program to promote health, work ability and well-being of aging workers in 1990-96. Helsinki: Finnish institute of Occupational Health; 1999.

40. Nilsson K. Arbetstillfredsställelse hos äldre läkare och sjuksköterskor. [Work satisfaction among older physician and nurses.] Malmö: Swedish National Institute of Working life; 2003. (In Swedish.)

41. Schnalzenberger M, Schneeweis N, Winter-Ebmer R, Zweimüller M. Job Quality and Retirement Decisions. In: Börsch-Supan A, et al, editors. Health, Ageing and Retirement in Europe (2004-2007). Starting the Longitudinal Dimension. Mannheim: Mannheim Research Institute for the Economics of Aging (MEA); 2008.

42. Ilmarinen J. Aging and Work - coping with strengths and weaknesses. Scand J Work Environ Health. 1997;23:suppl $1: 3-5$.

43. Lindgren G. Klass, kön och kirurgi. [Class, gender and surgery.] Malmö: Liber; 1999. (In Swedish.)
44. Tuomi K, Huuntanen P, Nykyri E, Ilmarinen J. Promotion of work ability, the quality of work and retirement. Occup Med. 2001;51.5:318-324. doi:10.1093/occmed/51.5.318.

45. Järnefelt N. Education and Longer Working Lives: A longitudinal study on education differences in late exit from working life among older employees in Finland. Helsinki: Finnish Centre for Pension Studies; 2010

46. Hirchman AO. Exit, Voice and Loyalty. Responses to Decline in Firms, Organizations, and States. London: Harvard University Press; 1970.

47. Marmot M. Status syndrome: how your social standing directly affects your health and life expectancy. London: Bloomsbury; 2004.

48. Vercruyssen M. Lifespan Functional Fitness: Encouraging Human Struggle (Physical Activity) and Warning About the Cost of Technology. In Kumashiro M, editor. Aging and Work. London: Taylor \& Francis; 2003.

49. Li C-Y, Sung F-C. A review of the healthy worker effect in occupational epidemiology. Occup Med. 1999; 49: 225-229. doi:10.1093/occmed/49.4.225.

50. Nilsson K. Förlängt arbetsliv - en litteraturgenomgång. [Extended working life - a literature review.] Malmö: Swedish National institute of Working life; 2003. (In Swedish.)

51. Karasek R, Theorell T. Healthy Work. Stress, Productivity and the Reconstruction of Working Life. New York: Basic Books; 1990.

52. Torgén M, Stenlund C, Ahlberg G, Marklund S. Ett hållbart arbetsliv för alla åldrar. [A sustainable working life to all ages.] Stockholm: Swedish National Institute of Working life; 2001. (In Swedish.)

53. Jönsson S, Tranquist J, Petersson H. Mellan klient och organization. Psykosocial arbetsmiljö i arbete med människor. [Between client and organization. Mental work environment in human service work.] Malmö: Swedish National Institute of Working life; 2003. (In Swedish.)

54. Antonovsky A. Unreveling the Mystery of Health - How People Manage Stress and Stay Well. San Francisco: JosseyBass Publishers; 1987.

Received for publication: 22 December 2010. 